\title{
On the Poroelastic Biot Coefficient for a Granitic Rock
}

\author{
A. P. S. Selvadurai $\mathbb{1}$
}

check for updates

Citation: Selvadurai, A.P.S. On the Poroelastic Biot Coefficient for a Granitic Rock. Geosciences 2021, 11, 219. https://doi.org/10.3390/ geosciences 11050219

Academic Editors: Mohamed Shahin and Jesus Martinez-Frias

Received: 10 March 2021

Accepted: 12 May 2021

Published: 17 May 2021

Publisher's Note: MDPI stays neutral with regard to jurisdictional claims in published maps and institutional affiliations.

Copyright: (C) 2021 by the author. Licensee MDPI, Basel, Switzerland. This article is an open access article distributed under the terms and conditions of the Creative Commons Attribution (CC BY) license (https:// creativecommons.org/licenses/by/ $4.0 /)$.
Environmental Geomechanics Laboratory, Department of Civil Engineering and Applied Mechanics, McGill University, Montreal, QC H3A 0C3, Canada; patrick.selvadurai@mcgill.ca

\begin{abstract}
The Biot coefficient is a parameter that is encountered in the theory of classical poroelasticity, dealing with the mechanics of a fluid-saturated porous medium with elastic grains and an elastic skeletal structure. In particular, the coefficient plays an important role in the partitioning of externally applied stresses between the pore fluid and the porous skeleton. The conventional approach for estimating the Biot coefficient relies on the mechanical testing of the poroelastic solid, in both a completely dry and a fully saturated state. The former type of tests to determine the skeletal compressibility of the rock can be performed quite conveniently. The latter tests, which determine the compressibility of the solid material constituting the porous skeleton, involve the mechanical testing of the fully saturated rock. These tests are challenging when the rock has a low permeability, since any unsaturated regions of the rock can influence the interpretation of the compressibility of the solid phase composing the porous rock. An alternative approach to the estimation of the solid grain compressibility considers the application of the multi-phasic theories for the elasticity of composite materials, to estimate the solid grain compressibility. This approach requires the accurate determination of the mineralogical composition of the rock using XRD, and the estimation of the elasticity characteristics of the minerals by appealing to published literature. This procedure is used to estimate the Biot coefficient for the Lac du Bonnet granite obtained from the western region of the Canadian Shield.
\end{abstract}

Keywords: Biot coefficient; Lac du Bonnet granite; multi-phasic estimates; compressibility of solids

\section{Introduction}

The management of heat-emitting and long-lived nuclear fuel waste is a topic of critical importance to many industrialized countries, such as Belgium, Canada, China, Finland, France, Germany, Japan, Korea, Switzerland, Sweden, Spain, USA, etc., which accumulated hazardous spent fuel over several decades of nuclear energy production. The used fuel is currently stored at or near the reactor sites. The environmental concerns become urgent as the reactors themselves age and become unsuitable options for even the temporary storage of the heat emitting wastes, due to maintenance and monitoring issues required over long periods. Many countries adopted disposal schemes that take advantage of stable geological formations. These include, clay deposits (Belgium), argillaceous shales (France), Opalinus clay (Switzerland), granitic rocks (Canada, China, Finland, Japan, Korea, Switzerland), volcanic tuff (USA), and salt formations (Germany). Recent reviews of highlevel nuclear waste disposal activities in various countries are given, among others, by Laughton et al. [1], Testa [2], Miller et al. [3], IAEA [4], NIREX [5], Stephansson et al. [6], Alonso et al. [7], Selvadurai et al. [8,9], Yardley et al. [10], Selvadurai and Suvorov [11], Faybishenko et al. [12], and Nguyen [13]. Canadian proposals for the deep geological disposal of non-heat-emitting nuclear fuel wastes focus on the creation of deep geological repositories in argillaceous sedimentary rock formations found in Southern Ontario. The Cobourg limestone was identified as a potential site for the creation of a deep ground repository (NWMO [14-17], OPG [18], Selvadurai [19]) for low- and intermediate-level waste. The granitic rocks of the Canadian Shield are potential locations for siting a deep, ground repository for storing heat-emitting, high-level nuclear fuel wastes. The Lac du 
Bonnet batholith, located on the western flank of the Canadian Shield, was investigated over the past four decades to assess its suitability for siting a deep ground repository for high-level wastes (Boulton [20]; Simmons and Baumgartner [21]; Johnson et al. [22]; Stevenson et al. [23]; Chandler [24]).

A typical geological setting in the Lac du Bonnet granitic rock formation contains sparse fracturing and the creation of a large underground opening in the highly stressed formation is expected to introduce excavation damage zones (EDZ) of varying severity. EDZ can alter the thermo-hydro-mechanical (THM) processes after the creation of a deep ground repository and the placement of heat-emitting nuclear fuel waste $[17,20-24]$ In regions remote from the excavations, the rock formations are expected to remain intact, except for the presence of any sparse fracturing. The THM processes in the intact granitic rock are therefore of considerable interest to the study of regions remote from the disposal galleries. In the remote regions, the rock mass is expected to be largely intact and its THM behavior can be described using the theory of thermo-poroelasticity. The classical theory of thermo-poroelasticity is an extension of the classical theory of poroelasticity developed by Biot [25] (see also Kumpel [26]; Cheng [27]). Extensive studies in this area generated a body of literature applicable to a wide class of problems in geomechanics and the geosciences. These include geological disposal of heat-emitting nuclear fuel waste, geologic sequestration of greenhouse gases, ground subsidence due to fluid withdrawal, energy resources extraction by thermal stimulation and hydraulic fracturing and the examination of geodynamics problems resulting from fluid injection. The studies in these areas are numerous and no attempt is made here to provide a comprehensive coverage. Important articles related to geotechnical and geoscience applications of THM behavior are provided in Selvadurai and Nguyen [28]; Selvadurai [29-34]; Khalili and Selvadurai [35]; Selvadurai and Shirazi [36]; Nguyen et al. [37]; Selvadurai and Suvorov [11,38,39]; Najari and Selvadurai [40]; and Selvadurai et al. [8]. In fluid-saturated porous media, the externally applied stresses are partitioned between the stresses carried by the porous skeleton and the stresses carried by the pore fluid. In classical theories of soil mechanics, the externally applied stresses are entirely borne by the pore fluid at the time of application of the stresses. This assumption concept does not address the elementary concept of load partitioning, respecting the deformability of both the porous skeleton and the skeletal material. The deformability-based partitioning process is an important development and impacts the initiation and development of failure, damage, and fracture of the porous skeleton. This, in turn, can alter the fluid transmissivity characteristics that are important to maintain the integrity of the waste disposal facility. In this sense, the classical theory of poroelasticity can be adopted as a canonical representation of the coupled hydro-mechanical behavior of intact rocks, which can be encountered in nuclear waste disposal endeavors.

\section{The Biot Coefficient}

The constitutive relations governing the coupled processes of mechanical deformations, fluid flow, and heat conduction in a fluid-saturated porous medium were shown by a number of investigators, and references to these developments are given by Selvadurai and Nguyen [28]. The dependent variables governing the THM processes are the displacements of the porous medium $\mathbf{u}(\mathbf{x}, t)$, the pore fluid pressure $p(\mathbf{x}, t)$, and the temperature $T(\mathbf{x}, t)$. These variables are specified at a point $\mathbf{x}$ of the porous medium, which is intended to provide an estimate of properties applicable to a Representative Volume Element (RVE). The governing equations take the forms:

$$
\begin{gathered}
\boldsymbol{\sigma}=G(\nabla \mathbf{u}+\mathbf{u} \nabla)+\left(\lambda \nabla \cdot \mathbf{u}-\beta K_{D}\right) \mathbf{I}+\alpha p \mathbf{I} \\
\mathbf{v}_{f}-\mathbf{v}_{s}=-\frac{K}{\eta}\left(\nabla p+\rho_{f} \mathbf{g}\right) \\
\mathbf{q}=-\kappa \nabla T
\end{gathered}
$$


where $\boldsymbol{\sigma}(\mathbf{x}, t)$ is the Cauchy stress tensor; $\mathbf{q}(\mathbf{x}, t)$ is the heat flux vector; $\mathbf{v}_{f}(\mathbf{x}, t)$ and $\mathbf{v}_{\mathcal{S}}(\mathbf{x}, t)$ are, respectively, the fluid velocity and the velocity of the solid skeleton; $G$ and $\lambda$ are the skeletal values of the Lamé constants; $K$ and $\eta$ are, respectively, the isotropic permeability and the dynamic viscosity; $\rho_{f}$ is the fluid mass density, $\mathbf{g}$ is the gravitational vector; $\beta$ is the thermal expansion coefficient. In Equation (1), $\alpha$ is the Biot coefficient defined by:

$$
\alpha=\left(1-\frac{K_{D}}{K_{S}}\right)
$$

where $K_{D}$ is the bulk modulus of the porous skeleton and $K_{S}$ is the bulk modulus of the solid material composing the porous skeleton. With soils, $K_{S}>>K_{D}$ with the result that $\alpha \rightarrow 1$. With rocks, the compressibility of the porous skeleton can be appreciable and the actual magnitude of the Biot coefficient can strongly influence the stress partitioning process. It should also be noted that in the classical theory of thermo-poroelasticity, the influence of the Biot coefficient occurs only in the constitutive relationship for the fluidsaturated porous medium, and all other processes are assumed to be uninfluenced by $\alpha$. If processes such as micro-cracking develop, then the governing equations can exhibit a dependency on the skeletal properties and the processes of fluid flow and heat conduction can also be indirectly influenced by the Biot coefficient.

The Biot coefficient incorporates scalar material properties of the solid phase as applied to the porous skeleton and the solid material. As such, experiments need to be conducted to determine their magnitudes. In principle, the procedures are straightforward. The skeletal bulk modulus for the porous medium can be determined by either (i) subjecting a completely dry sample of the rock to isotropic compression and measuring its volumetric strain, or (ii) subjecting a completely dry sample of the rock to uniaxial compression and measuring its elastic modulus and Poisson's ratio. These tests are quite routine and can be performed quite conveniently. It should be noted that defects in the fabric of the rock, such as micro-cracks and other defects, could be in an open condition. These can progressively close during the application of stresses to the sample. In the studies reported here, the measured material porosities are small enough to rule out the possible influences of defects in the fabric. Additionally, when pore closure occurs (either reversible or irreversible), it can cause a non-linear response in the initial stress-strain behavior of even granitic rock, as reported by Nur and Byerlee [41]. Alternatively, it can also cause irreversible processes leading to permeability hysteresis, as observed by Selvadurai and Głowacki [42]. The estimation of the compressibility of the solid material composing the porous skeleton requires complete saturation of the pore space of an unjacketed sample, which is then subjected to isotropic compression. The corresponding volume change is measured. This procedure is suitable when the fluid providing the cell pressure is identical to the fluid saturating the pore space. If the pressurizing fluid is similar to oil and the pore space is saturated with water, then the applied cell pressure is allowed to just equilibrate with the fluid pressure in the pore space. In this case, accurate servo-controlled pressure regulation is needed to perform the tests to estimate the compressibility of the skeletal solid material. Additionally, with low permeability rock, the control of the test should take the time lag into consideration, to achieve uniform fluid pressure within the sample. The volumetric strain of the specimen obtained from either unjacketed specimen testing or controlled jacketed specimen testing, provides an estimate of the bulk modulus of the solid material. Figure 1 schematically illustrates the concepts involved in the experimental procedures for estimating the Biot coefficient. 


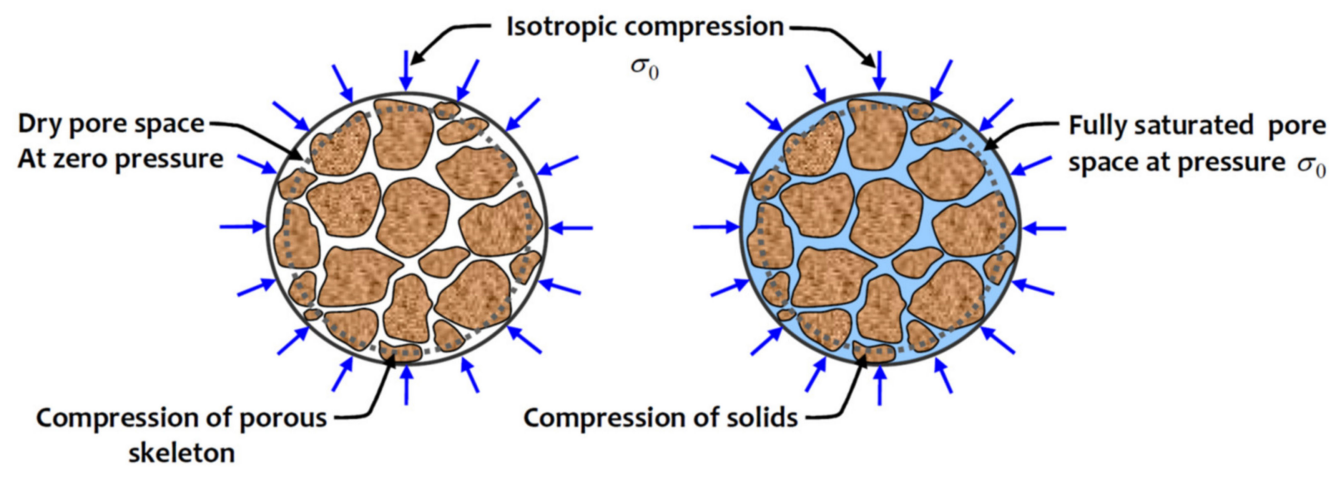

Figure 1. The experimental configurations for estimating the Biot coefficient.

The estimation of $K_{S}$ in particular can be quite difficult if the rock being tested shows a low permeability and possesses an internal fabric that requires testing of sufficiently large samples to capture an RVE. This problem was encountered when estimating the Biot coefficient for the Cobourg limestone, which has a low porosity in the range 0.001 to 0.006 , low permeability in the range $10^{-23} \mathrm{~m}^{2}$ to $10^{-19} \mathrm{~m}^{2}$, and most importantly, a nodular fabric with sizes in the range of $75 \mathrm{~mm}$. This necessitated testing large samples (150 $\mathrm{mm}$ in diameter and $300 \mathrm{~mm}$ in length) to capture an RVE (Selvadurai $[19,32,33])$. The procedure for saturating such a sample would be inordinately long with no assurance that the entire pore space was saturated. This could lead to an erroneous estimation of the volume change of the solid phase. Furthermore, internal pressurization of the pore space is a time-consuming diffusive process because of the low permeability of the rock and the large sample dimensions. The use of multi-phasic approaches, based on the mineralogical composition of the rock, to estimate the Biot coefficient of low permeability rocks, such as the Cobourg limestone, was proposed by Selvadurai [33]. This methodology was also successfully applied to estimate the Biot coefficient for Grimsel granite, which also has a low permeability and a transversely isotropic elastic fabric (Selvadurai et al. [43]). A review of the experimental methodologies for estimating the Biot coefficient for rocks and references to other investigations are presented by Kasani and Selvadurai [44]. In conventional definitions of the Biot coefficient, the porous medium is considered to be elastic. Even in studies that consider the possibility of failure and yield of the porous skeleton by appeal to a theory of plasticity (Pariseau [45]; Selvadurai and Suvorov [38,39]), the Biot coefficient is assumed to remain unaffected by alterations to the skeletal stiffness, following failure. Recently, Suvorov and Selvadurai [46] and Selvadurai and Suvorov [47] investigated, respectively, the definition of the Biot coefficient, when the skeletal fabric displayed elasto-plastic effects and how the pore shape affected the poroelastic parameter.

The use of multi-phasic approaches to estimate the bulk or effective elasticity properties of engineering materials dates back to the seminal studies by Voigt [48] and Reuss [49]. More formalized approaches to the estimation of the effective properties of multiphasic elastic properties of composite solids, based on variational approaches in elasticity, were developed by Hill [50,51], Hashin [52], Hashin and Shtrikman [53], Beran [54], and others. An estimation of the effective elasticity properties of rocks based on their mineralogical composition was provided by Brace [55]. The developments in this area are extensive and no attempt is made here to provide an exhaustive bibliography. Useful reference volumes by Christensen [56], Milton [57], Mavko et al. [58], Markov and Preziosi [59], and the references therein could be consulted for this purpose. In the context of the classical theory of poroelasticity, the use of the mineralogical composition of the rock in terms of their volume fractions, to estimate the compressibility of the solid material constituting the porous skeleton of the Cobourg limestone (Selvadurai et al. [60]) was proposed by Selvadurai [33]. Further discussions of the experimental methodologies for estimating the Biot coefficient of rocks and references to other investigations are given in Selvadurai and 
Suvorov [47]. In conventional definitions of the Biot coefficient, the porous medium and the constituent phases are both considered to be elastic.

The basis for the multi-phasic approach to estimate the bulk modulus of the solid material rests on the use of theoretical concepts for the estimation of bulk multi-phasic elastic composites. Several theoretical developments in this area are available (e.g., Voigt [48]; Reuss [49]; Hill [50]; Hashin [52]; Hashin and Shtrikman [53]; Walpole [61]; Hale [62]; Christensen [56]). The most widely used estimates are those due to Voigt [48] and Reuss [49] and the average measure proposed by Hill [50], i.e.,

$$
\left\{\left(K_{S}\right)^{V}=\sum_{i}^{n} V_{i}\left(K_{S}\right)_{i} ;\left(K_{S}\right)^{R}=\left(\sum_{i}^{n} \frac{V_{i}}{\left(K_{S}\right)_{i}}\right)^{-1}\right\} ;\left\{\begin{array}{l}
i \text { refers to the } \\
\text { mineral component }
\end{array}\right\}
$$

In Equation (5), the superscripts $V$ and $R$ refer, respectively, to the Voigt and Reuss estimates, $V_{i}$ are the mineralogical volume fractions and $\left(K_{S}\right)_{i}$ are the bulk modulus values for the individual mineral components. These two estimates can yield bounds that have a wide range and Hill [50] suggested the use of the algebraic means of the Voigt and Reuss estimates as a suitable alternative for the effective elastic properties of a multi-phasic elastic composite, as follows:

$$
\left(K_{S}\right)^{H}=\frac{1}{2}\left[\left(K_{S}\right)^{V}+\left(K_{S}\right)^{R}\right]
$$

This is a convenient estimate but there are no known rigorous proofs of either the validity or inadmissibility of the Hill [50] estimate. An obvious proof is that the average must always lie within the bounds. Thomsen [63] gives a useful discussion of the VoigtReuss-Hill average in the context of single crystal and polycrystalline aggregates and the role of the theory proposed by Kröner [64], for a perfectly disordered aggregate.

In this study, we use the bounds for the effective estimates for the $n$-phasic elastic composite proposed by Walpole [61], which gives the following estimate for the effective bulk modulus $K_{S}$ for the solid material:

$$
\left[\sum_{i=1}^{n}\left(\frac{V_{i}}{\left(K_{l}^{*}+K_{i}\right.}\right)\right]^{-1}-K_{l}^{*} \leq K \leq\left[\sum_{i=1}^{n}\left(\frac{V_{i}}{\left(K_{g}^{*}+K_{i}\right.}\right)\right]^{-1}-K_{g}^{*}
$$

where $i$ refers to the mineral component

$$
K_{l}^{*}=\frac{4}{3}\left(G_{S}\right)_{l} ; K_{g}^{*}=\frac{4}{3}\left(G_{S}\right)_{g}
$$

In Equation (8), $\left(G_{S}\right)_{l}$ and $\left(G_{S}\right)_{g}$ are, respectively, the lowest and largest values of the shear modulus of the $n$ mineral phases composing the multi-phasic elastic composite.

\section{Estimation of the Skeletal Compressibility of the Lac du Bonnet Granite}

The estimation of the skeletal bulk modulus requires test specimens that are completely free of moisture in the pore space. Cylindrical samples of the Lac du Bonnet granite measuring either $100 \mathrm{~mm}$ in diameter and $200 \mathrm{~mm}$ in length, or $150 \mathrm{~mm}$ diameter and $300 \mathrm{~mm}$ in length, were oven dried for over $168 \mathrm{~h}$ at $60^{\circ} \mathrm{C}$, to remove any moisture present after wet coring of the rock and air drying at room temperature, for periods in excess of one month. Periodic weighing of the sample was used to identify the attainment of a fully dried state. If the rock was relatively isotropic, the triaxial compression of an oven-dried jacketed test specimen and the measurement of the axial compression was sufficient to estimate the skeletal compressibility of the rock. When the sample had large dimensions, the test methodology was non-routine and required access to specialized testing facilities that could apply confining pressures of up to $60 \mathrm{MPa}$, to obtain sufficiently accurate measurements of the sample strains. An application of such a procedure for estimating the skeletal compressibility of the Cobourg limestone was presented in Selvadurai [33]. In this research, 
uniaxial compression tests were performed in an MTS Rock Testing Machine at strain rates of $0.01 \mathrm{~mm} / \mathrm{min}$ (Figure 2). Extensometers were used to measure the axial strains in the cylindrical samples (either $100 \mathrm{~mm}$ diameter and $200 \mathrm{~mm}$ in length, or $150 \mathrm{~mm}$ in diameter and $300 \mathrm{~mm}$ in length). The lateral strains were measured using $20 \mathrm{~mm}$ strain gauges (Figure 2). The compressive tests were conducted in a quasi-static load cycling mode and the stress-strain responses in the axial stress range of $30 \mathrm{MPa}$ and $40 \mathrm{MPa}$, were used to estimate the elasticity properties summarized in Table 1. This procedure eliminated any deformations due to contact asperities and enabled reliable interpretation of the elastic compression of the sample from the overall deformations recorded in the MTS Testing Machine.

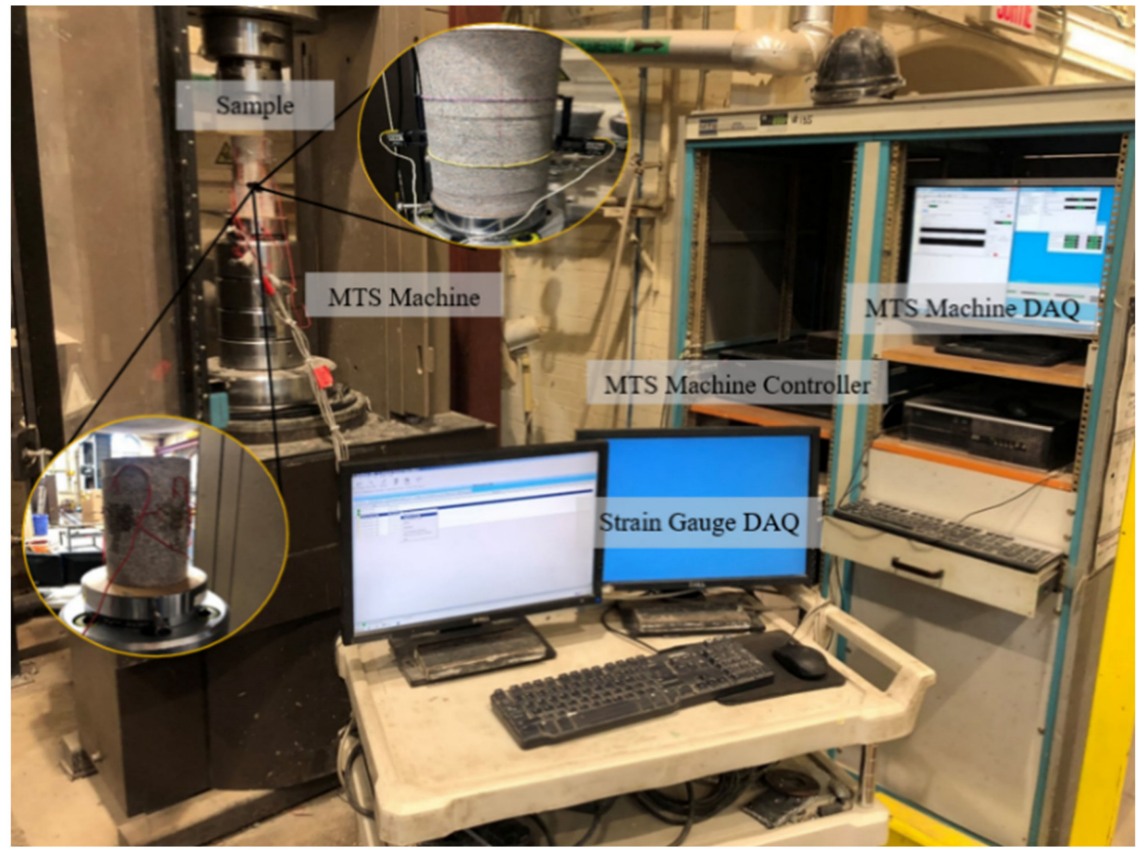

Figure 2. Experimental arrangement for performing uniaxial compression tests on the Lac du Bonnet granite cylinders.

Table 1. Elasticity properties of the Lac du Bonnet granite—Environmental Geomechanics Laboratory, McGill University.

\begin{tabular}{|c|c|c|c|}
\hline Testing Facility & Sample Dimensions & Young's Modulus & Poisson's Ratio \\
\hline $\begin{array}{c}\text { MTS Rock Testing } \\
\text { Machine }\end{array}$ & $\begin{array}{l}100 \mathrm{~mm} \text { diameter } \\
200 \mathrm{~mm} \text { long }\end{array}$ & $70.8 \mathrm{GPa}$ to $72.2 \mathrm{GPa}$ & 0.21 to 0.23 \\
\hline $\begin{array}{c}\text { MTS Rock Testing } \\
\text { Machine }\end{array}$ & $\begin{array}{l}150 \mathrm{~mm} \text { diameter } \\
300 \mathrm{~mm} \text { long }\end{array}$ & $70.4 \mathrm{GPa}$ & $\mathrm{N} / \mathrm{A}$ \\
\hline $\begin{array}{l}\text { HCLC Uniaxial } \\
\text { Testing Machine }\end{array}$ & $\begin{array}{l}150 \mathrm{~mm} \text { diameter } \\
300 \mathrm{~mm} \text { long }\end{array}$ & $72.0 \mathrm{GPa}$ & 0.213 \\
\hline
\end{tabular}

In a separate series of tests, uniaxial compression tests were performed on $150 \mathrm{~mm}$ diameter and $300 \mathrm{~mm}$ long samples of the Lac du Bonnet granite, using the High-Capacity Load Controlled (HCLC) Testing Facility available in the Environmental Geomechanics Laboratory at McGill University. This testing facility was successfully used for testing Cobourg limestone cylinders contained in an Obert-Hoek Cell (Selvadurai and Glowacki [65]). Figure 3 illustrates the instrumented Lac du Bonnet cylinder measuring $150 \mathrm{~mm}$ in diameter and $300 \mathrm{~mm}$ in length. Three $30 \mathrm{~mm}$ long strain gauges were installed at the mid-section of the cylinder at $120^{\circ}$ spacing to measure the longitudinal strains, and three strain gauges of length $30 \mathrm{~mm}$ were installed at the mid-section of the cylinder, in an offset fashion, to measure the circumferential strains. Using the HCLC Testing Facility, the axial stress was 
first increased to $20 \mathrm{MPa}$ and then quasi-statically increased from $20 \mathrm{MPa}$ to $30 \mathrm{MPa}$ to estimate the elasticity properties of the rock. The maximum stress applied to the sample was significantly lower than the compressive failure strength of the dry rock, which was estimated to be approximately $125 \mathrm{MPa}$ (TCNA [66]), but values in excess of $200 \mathrm{MPa}$ were also recorded (Martin and Chandler [67]). The Lac du Bonnet granite is classified as a fine-grained homogeneous granite. The fabric of the Lac du Bonnet rock samples tested did not display any dominant stratifications, heterogeneities, or defects. Therefore, for the purpose of estimating the elasticity properties, the granite could be modelled as an isotropic rock. Existing studies of the Lac du Bonnet granite [67-70] do not indicate any evidence of a dominant anisotropy. The experimental data on the Lac du Bonnet granite gave elasticity properties that are summarized in Table 1. All experiments were performed under uniform laboratory conditions. The isothermal isotropic elasticity properties of the Lac du Bonnet granite were also determined by a number of other investigators, including Martin and Stimpson [68], Jackson et al. [69], Stone et al. [70], Carter et al. [71], and Read and Martin [72]. Data from this latter article was also referred to in several publications. Table 2 provides a summary of the elasticity properties for the Lac du Bonnet granite that is available in the literature.
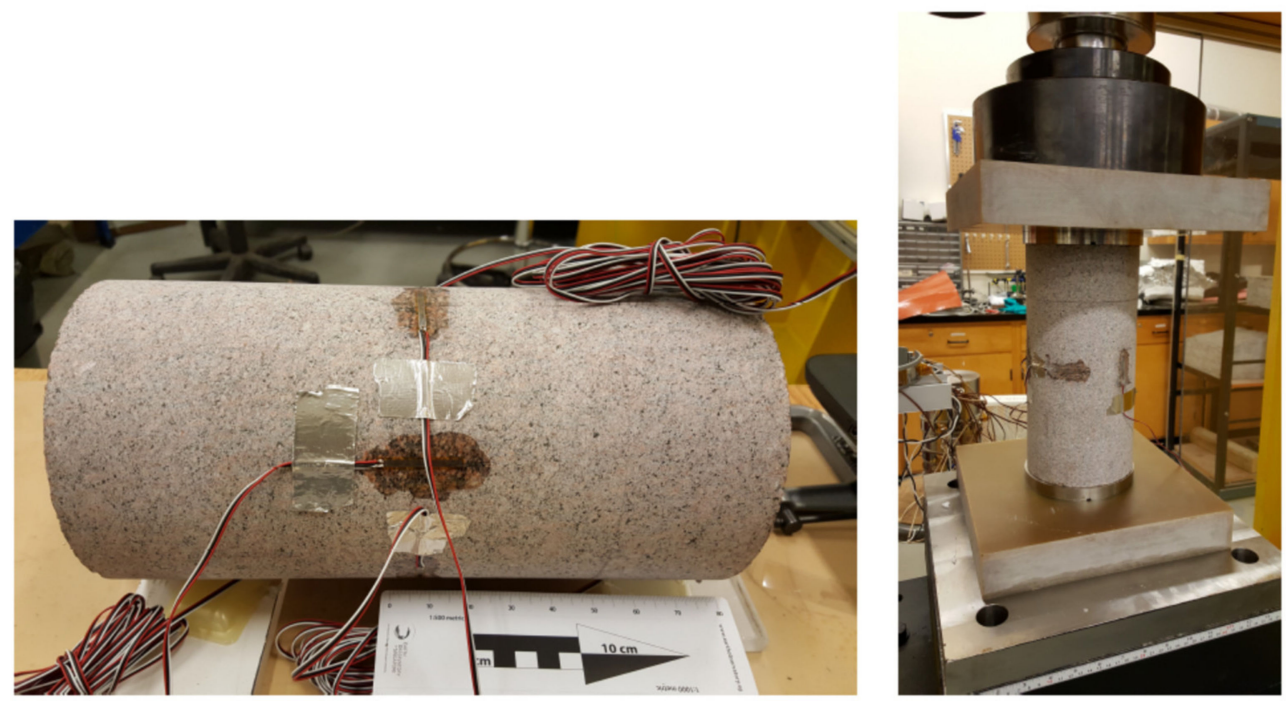

Figure 3. The instrumented $150 \mathrm{~mm}$ diameter cylinder of the Lac du Bonnet granite.

Table 2. Elasticity properties of the Lac du Bonnet granite from the published literature.

\begin{tabular}{ccc}
\hline Reference & Young's Modulus & Poisson's Ratio \\
\hline Jackson et al. [69] & $68.0 \mathrm{GPa}$ & 0.24 \\
Stone et al. [70] & $66.7 \mathrm{GPa}$ & 0.27 \\
Carter et al. [71] & $70.0 \mathrm{GPa}$ & 0.21 \\
Read and Martin [72] & $(65.0 \pm 5) \mathrm{GPa}$ & $(0.25 \pm 0.05)$ \\
Martin and Stimpson [68] & $68.0 \mathrm{GPa}$ & 0.26 \\
\hline
\end{tabular}

Considering the elasticity measurements made in the Environmental Geomechanics Laboratory at McGill University, we assumed the following values for the elastic constants, recognizing the slightly lower value obtained in other studies.

$$
E \simeq 70 \mathrm{GPa} ; v \simeq 0.21
$$

The bulk modulus for the porous skeleton is given by

$$
K_{D}=\frac{E}{3(1-2 v)} \simeq 40.23 \mathrm{GPa}
$$




\section{Estimation of the Mineralogical Composition of the Lac du Bonnet Granite}

We now focus attention on the application of the multi-phasic approach to estimate the compressibility of the solid materials constituting the porous skeleton. The first task in such a procedure involves determining the mineralogical composition of the Lac du Bonnet granite. This was extensively examined in several studies, including those by Tammemagi et al. [73], Chernis and Robertson [74], Duevel and Haimson [75], Eberhardt et al. [76], and Lukkarila [77]. In this research, the mineralogical composition of the Lac du Bonnet granite was determined using the Bruker D8 Discovery X-ray Diffractometer facilities (Figure 4) available at the McGill Institute for Advanced Materials (MIAM).
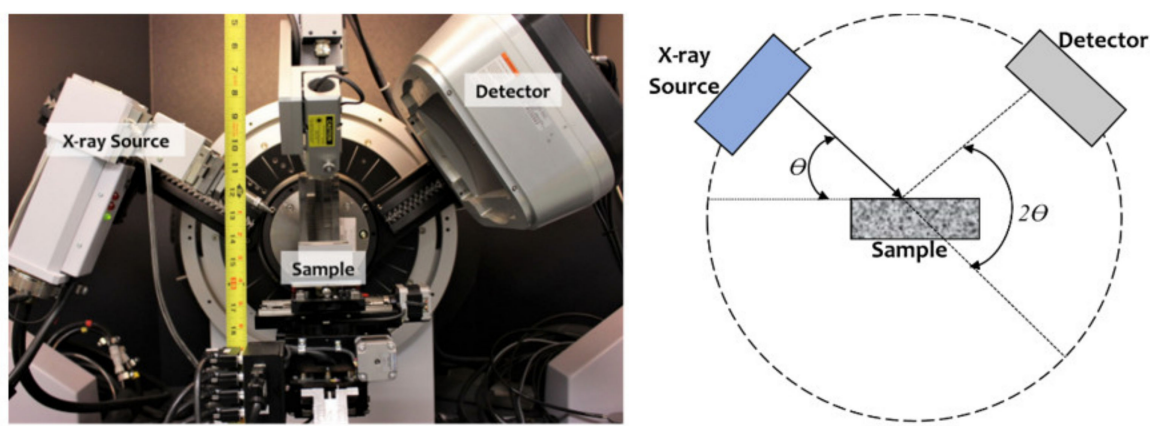

Figure 4. The Bruker D8 Discovery X-ray Diffractometer and a schematic view of the detector position-MIAM.

A small ( $15 \mathrm{cc})$ sample of the Lac du Bonnet granite was crushed using a mortar and pestle and sieve analysis was repeatedly performed to prepare a fine powder with particle sizes less than $75 \mu \mathrm{m}$ (Figure 5). The remaining larger particles were retained for XRD testing to verify any influence of the particle size on the XRD results. The XRD results on the samples, both above and below the $75 \mu \mathrm{m}$ particle size, produced similar data, and the finer particle size was used in the investigation.

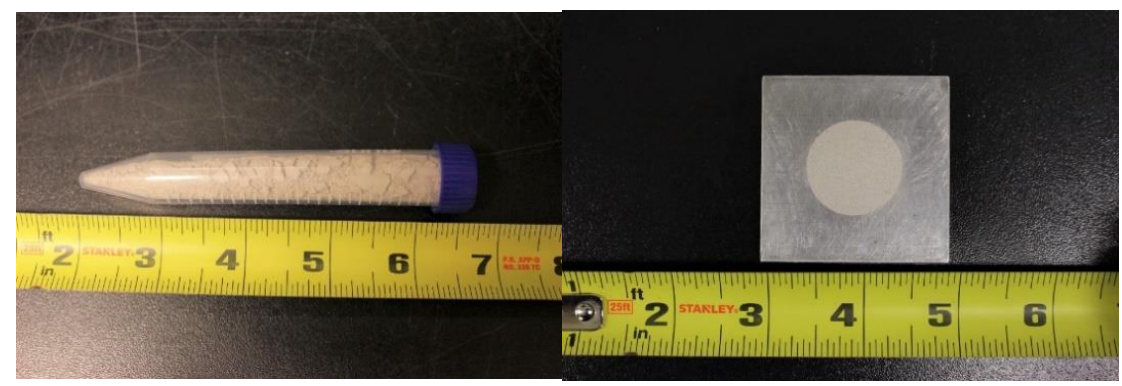

(a)

(b)

Figure 5. The Lac du Bonnet granite sample. (a) Sample with grain size less than $75 \mu \mathrm{m}$. (b) Sample prepared for XRD testing.

A typical XRD result is shown in Figure 6. An X-ray source emitted incident rays to the sample and at each angle the detector recorded the intensity of the reflected $\mathrm{x}$-rays as counts ( $y$ axis of Figure 6). The detector moved around the sample in a circular motion and its position was recorded at every angle $2 \theta$, which corresponded to the $x$-axis of the resulting diffractogram. Since there was a unique diffraction pattern for each phase or specific chemistry and atomic arrangement, the diffraction pattern could be used to determine the mineralogical composition. The interpretation of the mineralogical composition was performed using custom software. If the rock being examined had a high composition of clay minerals $(>2 \%)$, the sample preparation required operator experience, and the interpretation of the XRD data needed to be carried out using the RIETVELD approach (Rietveld [78]). This procedure was used for the estimation of the mineralogical composition of the Cobourg limestone 
(Waber et al. [79]; Selvadurai and Rezaei Niya [80]). In the case of the Lac du Bonnet granite, the mineralogical composition contained only traces of clay minerals, so the XRD data could be analyzed using the DIFFRAC.EVA [81] software available at the MIAM. The peaks in the graphs and the $d$-spacing (the distance between adjacent atomic planes) were analyzed to determine the mineralogical compositions of the sample. To perform the analysis, specific minerals were searched for in the system and the DIFFRAC.EVA software estimated the percentage volume of that mineral in the sample. In this study, the minerals present were quartz, feldspar, and mica. No further subgroups were considered.

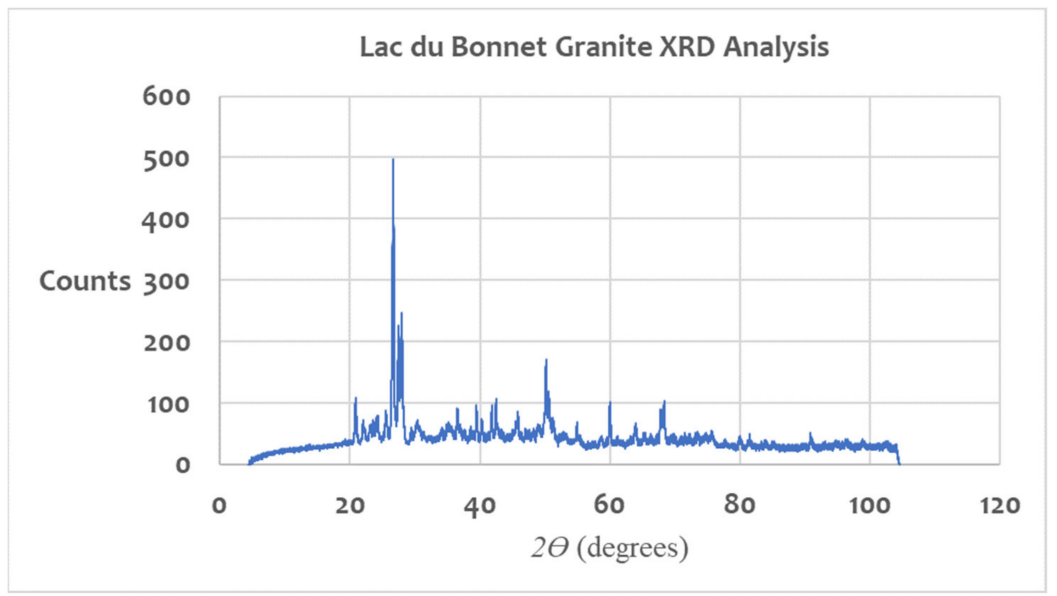

Figure 6. X-ray diffractogram of Lac du Bonnet granite powder.

Table 3 summarizes the mineralogical compositions obtained by various other researchers (Tammemagi et al. [73]; Chernis and Robertson [74]; Duevel and Haimson [75]; Eberhardt et al. [76]; Lukkarila [77]) and the results from the MIAM. In general, there is reasonable agreement in terms of the dominant mineralogical groups; minor variations are to be expected, depending on the location of the sample in the Lac du Bonnet batholith. The results obtained at the MIAM were used in subsequent calculations.

Table 3. Mineralogical composition of the Lac du Bonnet granite.

\begin{tabular}{cccc}
\hline Reference & Quartz (\%) & Feldspar (\%) & Mica, etc. (\%) \\
\hline MIAM & 38.4 & 60.2 & 1.4 \\
Tammemagi et al. [73] & 30.0 & 65.0 & 5.0 \\
Chernis \& Robertson [74] & 30.6 & 64.8 & 4.6 \\
Duevel \& Haimson [75] & 30.0 & 60.0 & 10.0 \\
Eberhardt et al. [76] & 30.0 & 65.0 & 5.0 \\
Lukkarila [77] & 34.0 & 56.0 & 10.0 \\
\hline
\end{tabular}

\section{The Compressibility of the Solid Material Composing the Lac du Bonnet Granite}

In order to use the theoretical developments for the estimation of the compressibility of the solid material composing the porous skeleton of the Lac du Bonnet granite, it was necessary to obtain the elasticity properties of the basic mineral groups that make up the solid material. Most of the mineral groups have elasticity properties that are anisotropic, transversely isotropic, or isotropic. The measurement of the elasticity properties required access to sophisticated experimental facilities that were non-routine. The effective elasticity properties of the solid crystals were provided by a number of investigators, including Alexandrov et al. [82], Anderson and Nafe [83], Carmichael [84], Mavko et al. [58], and Wenning et al. [85]; references to further studies are also given in Selvadurai [33] and Selvadurai et al. [43]. The bulk moduli $\left(K_{S}\right)$ and shear moduli $\left(G_{S}\right)$ for the minerals identified in the Lac du Bonnet Granite are shown in Table 4. Even though the constituent minerals themselves were anisotropic, the estimates for the effective elastic constants were given as 
representative isotropic estimates. This was a limitation of any multi-phasic approach, and to remove this constraint, an inordinate amount of experimentation was necessary to determine the anisotropic properties at the crystallographic scale. The experimental results were approximate estimates but were considered to be sufficient for determining the effective compressibility of other granitic rocks, such as the Grimsel granite (Selvadurai et al. [43]). Considering the multi-phasic approach, the expressions for the Voigt [48] and Reuss [49] bounds given by Equation (5) and the data in Table 4, we obtained the following bounds for the compressibility of the solid material of the Lac du Bonnet granite:

$$
\left(K_{S}\right)^{R}=54.8 \mathrm{GPa} \leq K_{S} \leq\left(K_{S}\right)^{V}=61.2 \mathrm{GPa}
$$

Table 4. The MIAM Mineralogical composition and $K_{S}$ and $G_{S}$ values for the solid phases of the Lac du Bonnet granite.

\begin{tabular}{ccccc}
\hline Mineral & Specific Gravity & $\mathbf{( \% )}$ & $K_{S}(\mathbf{G P a})$ & $G_{S}(\mathbf{G P a})$ \\
\hline Quartz & 2.72 & 38.4 & 38 & 45 \\
Feldspar & 2.60 & 60.2 & 76 & 26 \\
Mica, etc & 2.70 & 1.4 & 61 & 41 \\
\hline
\end{tabular}

The average attributed to Hill [50] gives

$$
\left(K_{S}\right)^{H}=58 \mathrm{GPa}
$$

In order to calculate the estimates provided by Walpole [61], we used

$$
K_{l}^{*}=34.67 \mathrm{GPa} ; K_{g}^{*}=60.00 \mathrm{GPa}
$$

From Equation (12) and the results presented in Table 4, we obtained the following set of bounds for the effective bulk modulus for the solid phase:

$$
57.33 \mathrm{GPa} \leq K_{S} \leq 58.20 \mathrm{GPa}
$$

\section{Estimates of the Biot Coefficient for the Lac du Bonnet Granite}

As was evident from Equations (11) and (13), the theoretical predictions obtained from the Hill [50] and Walpole [61] approaches were relatively close and confirmed the suitability of the multi-phasic approach for estimating the effective bulk modulus for the solid phase of the porous skeleton of the Lac du Bonnet granite. It should be noted that the multi-phasic estimates presented here did not account for the void phase of the Lac du Bonnet granite. The porosity of the Lac du Bonnet granite examined in the Environmental Geomechanics Laboratory at McGill University (Selvadurai et al. [9]) was estimated to be approximately $0.26 \%$. Therefore, the influence of the porosity on the overall compressibility of the solid phase was considered to be negligible. For a hollow sphere model of a porous medium, the equivalence of strain energy of the hollow sphere was subjected to radial compression with the strain energy of a solid sphere, with an equivalent effective bulk modulus $\left(K_{S}\right)_{\text {Porous }}$ subjected to radial compression could be obtained in the form (see e.g., Hashin and Shtrikman [53], Ramakrishnan and Arunachalam [86]):

$$
\left(K_{S}\right)_{\text {Porous }}=K_{S}\left(\frac{1-\varphi}{1+\left(\frac{1-v_{S}}{2\left(1-2 v_{S}\right)}\right) \varphi}\right)
$$

where $v_{S}$ is Poisson's ratio of the solid phase and $\varphi$ is the porosity. From (14) it is evident that if $\varphi \ll 1$ and $0 \leq v_{S}<1 / 2$, the porosity had a negligible influence on the estimation of the compressibility of the solid phase. Therefore, for a very low porosity rock similar to the Lac du Bonnet granite with $\varphi \simeq 0.0026$ and $v_{S}=0.21,\left(K_{S}\right)_{\text {Porous }}=0.9956 K_{S}$. Hence, 
the influence of the porosity on the estimation of the compressibility of the solid phase could be neglected.

The estimates for the solid material compressibilities of the Lac du Bonnet granite given by Equation (13) and the skeletal compressibility given by Equation (9) could be used to provide the bounds for the Biot coefficient, as follows:

$$
0.30 \leq \alpha \leq 0.31
$$

The value for the Biot coefficient as predicted by Equation (15) was in keeping with the estimate for very low porosity granites that had $\alpha \in(0.18,0.48)$ for $\varphi \in(0.005,0.01)$. Similar conclusions were supported in a recent study by Selvadurai and Suvorov [47]. Some typical experimental results that relate the Biot coefficient to the porosity are shown in Figure 7.

The results given by Lau and Chandler [87] were the only known estimates for the Biot coefficient of the Lac du Bonnet granite. Their studies (Table 2 of Lau and Chandler [87]) recorded a value of $\alpha=0.73$. Referring to this data, the elastic modulus of the porous skeleton (Figure 1 of Lau and Chandler [87]) was estimated to be approximately $E=80 \mathrm{GPa}$. Assuming that the Poisson's ratio for the skeletal material $v=0.2$, the estimated value for the skeletal bulk modulus $K_{D} \simeq 44 \mathrm{GPa}$. This was reasonably close to the experimentally determined value for $K_{D} \simeq 40 \mathrm{GPa}$ for the Lac du Bonnet granite reported here. The value quoted for $K_{D}$ (i.e., skeletal compressibility) in Table 2 of Lau and Chandler [87] was, however, $K_{D} \simeq 15 \mathrm{GPa}$, which was significantly smaller. The estimate for the experimentally determined bulk modulus of the solid phase of the Lac du Bonnet granite given Lau and Chandler [87] (Figure 24 and Table 2) was $K_{S} \simeq 55 \mathrm{GPa}$ and this also agreed closely with the multi-phasic estimate of $K_{S} \simeq 57.5 \mathrm{GPa}$, obtained as the average of the two bounds given in Equation (13). Here again, the experimental data and theoretical predictions were very close. If the data presented in Table 2 of Lau and Chandler [87] were used, the Biot coefficient $\alpha \simeq 0.73$, and according to the present study, $0.30 \leq \alpha \leq 0.31$. The investigation by Rutqvist et al. [88] noted the relatively high value for the Biot coefficient given in Lau and Chandler [87] but assigned an arbitrary value of $\alpha \simeq 0.20$ for the granite from the Lac $\mathrm{du}$ Bonnet Underground Research Laboratory. The extent to which the value of $\alpha \simeq 0.73$ was used in other research (Chan and Stanchell [89]) that made use of the data derived in Lau and Chandler [87] needs further investigation.

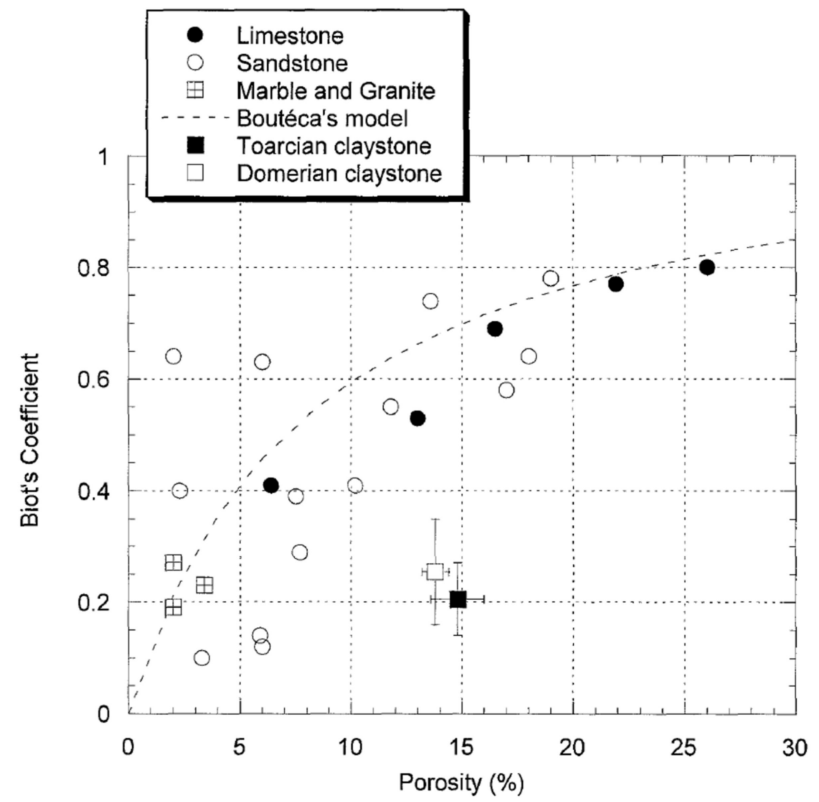

Figure 7. Experimental observation of the relationship of the Biot coefficient to porosity (Cosenza et al. [90]). [Data also attributed to Rice and Cleary [91], Cheng and Detournay [92], Boutéca and Sarda [93], Charlez [94], and Fabre and Gustkiewicz [95]]. 
Values for the Biot coefficient for a variety of rocks were compiled by many investigators (Berryman [96]; Wang [97]; Rice and Cleary [91]; Cosenza et al., [90] Lau and Chandler [87]; Mavko et al. [58]; and Kasani and Selvadurai [44]). Table 5 provides values reported in the literature for the Biot coefficient for low permeability materials such as marble, granite, and other crystalline low permeability rocks. The estimation of the Biot coefficient for other rock types, including sandstone, limestone, clay shales, coal, etc. were given by many authors and references to these studies can be found in the articles cited previously and those by Souley et al. [98] for sandstone, Hu et al. [99] for sandstone, Chen et al. [100] for coal, Selvadurai et al. [101] for tight sandstone, Braun et al. [102] for the Callovo-Oxfordian claystone, and Selvadurai [33] for low permeability limestone, etc.

In some instances referred to in Table 5, the Biot coefficient was measured and in others the value was estimated. Additionally, in this context, the listing of the porosity of the rock was an important consideration. It must be emphasized that the values reported were taken at face value and no attempt was made to review the original experimental data. In connection with an ongoing study, the mineralogical composition of the Stanstead granite was estimated to be $38.6 \%$ Quartz; 58.9\% Feldspar, and approximately 2.5\% Mica and other minerals. The porosity of the Stanstead granite was estimated to be approximately 0.0077 . Using the multi-phasic approaches presented previously, $K_{D} \simeq 58 \mathrm{GPa}$. The skeletal elasticity properties of the Stanstead granite given by Chen and Xia [103] were as follows: $E \simeq 66 \mathrm{GPa} ; v \simeq 0.16$, corresponding to $K_{D} \simeq 32.35 \mathrm{GPa}$. The Biot coefficient for the Stanstead granite was estimated to be $\alpha=0.44$, which was the value used by Najari and Selvadurai [40], based only on the values applicable for the granitic rocks suggested by Wang [104]. Finally, Zimmerman [105,106] obtained the following set of bounds for the Biot coefficient in terms of the porosity, as follows:

$$
\left(\frac{3 \varphi}{2+\varphi}\right) \leq \alpha \leq 1
$$

Table 5. Biot coefficients for low permeability rocks such as granite and marble.

\begin{tabular}{cccc}
\hline Reference & Rock Designation & Porosity & Biot Coefficient \\
\hline Brace [55] & Stone Mountain & 0.003 & 0.027 to 0.86 \\
Schmitt and Zoback [107] & Kent Cliffs cryst. rock & 0.0015 & 0.24 to 0.68 \\
Berryman [96] & Barre granite & 0.007 & 0.75 \\
Berryman [96] & Westerly granite & 0.008 & 0.55 \\
Berryman [96] & Chelmsford granite & 0.011 & 0.85 \\
Selvadurai \& Nguyen [28] & Canadian Shield & 0.005 & 0.60 \\
Cosenza et al. [90] & Tennessee marble & 0.02 & 0.19 \\
Cosenza et al. [90] & Charcoal granite & 0.02 & 0.27 \\
Cosenza et al. [90] & Westerly granite & 0.01 & 0.47 \\
Chan and Stanchell [89] & Lac du Bonnet granite & 0.002 & 0.73 \\
Najari and Selvadurai [40] & Stanstead granite & 0.007 & 0.44 \\
Duan and Skoczylas [108] & Beishan granite & 0.0005 & 0.70 to 0.90 \\
Tan and Konietzky [109] & Aue granite & 0.0158 to 0.023 & 0.35 to 0.41 \\
Selvadurai et al. [43] & Grimsel granite & 0.0048 & 0.48 to 0.71 \\
Lau and Chandler [87] & Lac du Bonnet granite & 0.002 & 0.73 \\
Current Study & Stanstead granite & 0.0077 & 0.44 \\
Current Study & Lac du Bonnet granite & 0.0026 & 0.30 \\
\hline
\end{tabular}

(Many of the estimates were based on either purely experimental results or experimental results supplemented by multi-phasic estimates. The values reported by Berryman [96] were attributed to Coyner [110]).

For the porosity of the Lac du Bonnet granite ( $\varphi \simeq 0.007$ ), the lower limit of Equation (16) gave $\alpha=0.01$, which was clearly an unreasonably low value. In this sense, the bounds Equation (16) should also be accompanied with a limit of applicability of the porosity range. 


\section{Concluding Remarks}

The Biot coefficient was an important advance in the treatment of stress partitioning in both hydro-mechanical and thermo-hydro-mechanical processes applicable to the fluidsaturated porous media. In its elementary form, the Biot coefficient was only governed by the skeletal compressibility and the sold material compressibility of the porous medium. The experimental determination of these two parameters needs to consider the scale at which these material parameters were determined. If the fabric of the porous medium contained defects and other void spaces, the representative volume element must address the scale, and the parameters determined should be scale-independent. Visual inspection of a rock at any scale does not provide a complete picture of its mechanical and physical properties. In the study presented in [111], a $450 \mathrm{~mm}$ cuboid of Indiana Limestone that displayed a relatively homogeneous fabric was found to exhibit significant spatial variation of the permeability. The estimation of the skeletal compressibility of the porous medium was relatively straightforward, irrespective of the porosity of the medium. The estimation of the solid material compressibility could also be influenced by the accessible pore space and pore spaces that required time for fluid migration and for the attainment of uniform pore space pressure, for compression of the solid material. This deficiency could be overcome by using a multi-phasic approach to estimate the solid material compressibility. Several theories developed for the study of multi-phasic composite materials could be successfully applied to estimate the compressibility of the solids. The Voigt-Reuss-Hill relationships give almost the same value for the average of the bounds given by Walpole [61]. In general, the skeletal compressibility, which is influenced by the porosity of the rock tends to have an appreciable influence on the Biot coefficient. (i.e., the larger the porosity the lower the value of $K_{D}$, while $K_{S}$ is sensibly constant). The research provides estimates of the Biot coefficient for the low porosity Lac du Bonnet granite, which was found to be $\alpha \simeq 0.3$. Other researchers obtained higher values for the Biot coefficient and the factors leading to the discrepancies were not immediately evident. Processes such as macro-cracking could lead to a reduction in the skeletal compressibility $K_{D}$ and the low porosity could refer to the intact regions of the rock. This study underscored the importance of estimating the skeletal elasticity characteristics of the dry rock and demonstrated the effective use of the mineralogical composition of the rock by XRD analysis, to develop results for the compressibility of the solid material.

Author Contributions: The scope and the experimental and theoretical approaches discussed in this paper were developed by the author. The assistance of technical staff and other personnel is indicated in the acknowledgements. The author was solely responsible for writing the paper.

Funding: This research was supported through an NSERC Discovery Grant (RGPIN/04676-2016); Distinguished James McGill Professorship Grant (101086); NWMO Research Grant (248841).

Institutional Review Board Statement: Not applicable.

Informed Consent Statement: Not applicable.

Data Availability Statement: No specific codes were used in the preparation of the paper. All data used in the preparation of the paper are included in the presentation.

Acknowledgments: This work was supported through NSERC Discovery and Research Tools Grants, the Research support provided by the Nuclear Waste Management Organization of Ontario and the Distinguished James McGill Research Chairs program. The author gratefully acknowledges the highly constructive comments on the manuscript provided by the reviewers. The Staff at Geoscience Research and Development at NWMO are thanked for their continued support and interest in the research activities. The author is grateful to the Technical and Research support provided by J. Bartczak, W. Boyd-Dumais and the research students in the Environmental Geomechanics Laboratory at McGill University, including J. Cardelle, A. Blain-Coallier, R. Hemmati, V. Zasmolin, and P. Samea.

Conflicts of Interest: There are no conflict of interest. 


\section{References}

1. Laughton, A.S.; Roberts, L.E.J.; Wilkinson, D.; Gray, D.A. The Disposal of Long-lived and Highly Radioactive Wastes. In Proceedings of the Royal Society Discussion Meeting, London, UK, 30 May 1985; Royal Society: London, UK, 1986.

2. Testa, S.M. Geological Aspects of Hazardous Waste Management; CRC Press: Boca Raton, FL, USA, 1994.

3. Miller, W.; Alexander, R.; Chapman, N.; McKinley, J.C.; Smellie, J.A.T. Geological Disposal of Radioactive Wastes and Natural Analogues; Waste Management Series; Pergamon Press: Amsterdam, The Netherlands, 2000; Volume 2.

4. IAEA. Scientific and Technical Basis for Geologic Disposal of Radioactive Waste; Technical Reports Series No. 413; International Atomic Energy Agency: Vienna, Austria, 2000.

5. NIREX. A Review of the Deep Borehole Disposal Concept for Radioactive Waste; Report No. N/108; Nirex Limited: Didcot, UK, 2004.

6. Stephansson, O.; Hudson, J.; Jing, L. (Eds.) Coupled Thermo-Hydro-Mechanical-Chemical Processes in Geo-Systems: Fundamentals, Modelling, Experiments and Applications; Elsevier Geo-Engineering Book Series; Elsevier: Amsterdam, The Netherlands, 2004.

7. Alonso, E.; Alcoverro, J.; Coste, F.; Malinsky, L.; Merrien-Soukatchoff, V.; Kadiri, I.; Nowak, T.; Shao, H.; Nguyen, T.; Selvadurai, A.; et al. The FEBEX benchmark test: Case definition and comparison of modelling approaches. Int. J. Rock Mech. Min. Sci. 2005, 42, 611-638. [CrossRef]

8. Selvadurai, A.P.S.; Suvorov, A.P.; Selvadurai, P.A. Thermo-hydro-mechanical processes in fractured rock formations during a glacial advance. Geosci. Model Dev. 2015, 8, 2167-2185. [CrossRef]

9. Selvadurai, A.P.S.; Blain-Coallier, A.; Selvadurai, P.A. Estimates for effective permeability of intact granite obtained from the eastern and western flanks of the Canadian Shield. Minerals 2020, 10, 667. [CrossRef]

10. Yardley, B.W.D.; Ewing, R.C.; Whittleston, R.A. (Eds.) Deep-mined geological disposal of radioactive waste. Elements 2016, 12, 233-274. [CrossRef]

11. Selvadurai, A.P.S.; Suvorov, A.P. Thermo-Poroelasticity and Geomechanics; Cambridge University Press: Cambridge, UK, 2016.

12. Faybishenko, B.; Birkholzer, J.; Sassani, D.; Swift, P. (Eds.) International Approaches for Deep Geological Disposal of Nuclear Waste: Geological Challenges in Radioactive Waste Isolation. In Fifth Worldwide Review; LBNL-1006984; Lawrence Berkeley National Laboratory, Sandia National Laboratories: Albuquerque, NM, USA, 2016.

13. Nguyen, T.S. Progressive damage of a Canadian granite in laboratory compression tests and underground excavations. Minerals 2021, 11, 10. [CrossRef]

14. NWMO. People, Science, Indigenous Knowledge. Moving Towards Partnership. In Annual Report of the Nuclear Waste Management Organization; NWMO: Toronto, ON, Canada, 2017; pp. 1-104.

15. NWMO. Ontario Power Generation's Deep Geologic Repository for Low and Intermediate Level Waste, Post-Closure Safety Assessment, NWMO DGR-TR-2011-25; NWMO: Toronto, ON, Canada, 2011.

16. NWMO. Ontario Power Generation's Deep Geologic Repository for Low and Intermediate Level Waste, Geosynthesis, NWMO DGR-TR2011-11; NWMO: Toronto, ON, Canada, 2011.

17. NWMO. NWMO's Program for Research and Development for Long-Term Management of Used Nuclear Fuel; NWMO TR-2019-18; Nuclear Waste Management Organization: Toronto, ON, Canada, 2019.

18. OPG 2016. Ontario Power Generation's Deep Geologic Repository for Low and Intermediate Level Waste: DGR: Protecting Lake Huron: Ontario Power Generation. Available online: www.opg.com/dgr (accessed on 12 May 2020).

19. Selvadurai, A.P.S. Geomechanical Characterization of the Cobourg Limestone; Nuclear Waste Management Organization Technical Report NWMO-TR-2017-7; NWMO: Toronto, ON, Canada, 2017.

20. Boulton, J. (Ed.) Management of Radioactive Wastes: The Canadian Disposal Program; Atomic Energy of Canada Limited Report AECL-6314; Whiteshell Laboratories: Pinawa, MB, Canada, 1978.

21. Simmons, G.R.; Baumgartner, P. The Disposal of Canada's Nuclear Fuel Waste: Engineering for a Disposal Facility; AECL Res Rep AECL-10715, COG-93-5; Whiteshell Laboratories: Pinawa, MB, Canada, 1994.

22. Johnson, L.H.; LeNeveau, D.M.; Shoesmith, D.W.; Oscarson, D.W.; Gray, M.N.; Lemire, R.J.; Garisto, C. The Disposal of Canada's Nuclear Fuel Waste: The Vault Model for Post-Closure Assessment; AECL Research Report AECL-1071; Whiteshell Laboratories: Pinawa, MB, Canada, 1994.

23. Stevenson, D.R.; Kozak, E.T.; Davison, C.C.; Gascoyne, M.; Broadfoot, R.A. Hydrogeologic Characteristics of Domains of Sparsely Fractured Rock in the Granitic Lac du Bonnet Batholith; AECL-11558, COG-96-117; Atomic Energy of Canada Limited: Chalk River, ON, Canada; Whiteshell Laboratories: Pinawa, MB, Canada, 1996.

24. Chandler, N.A. Twenty-five years of underground research at Canada's URL. In Proceedings of the Waste Management Conference, Tucson, AZ, USA, 23-27 February 2003; pp. 1-15.

25. Biot, M.A. General theory of three-dimensional consolidation. J. Appl. Phys. 1941, 12, 155-164. [CrossRef]

26. Kumpel, H.-J. Poroelasticity: Parameters reviewed. Geophys. J. Int. 1991, 105, 783-799. [CrossRef]

27. Cheng, A.H.-D. Poroelasticity; Springer: Berlin, Germany, 2016.

28. Selvadurai, A.; Nguyen, T. Computational modelling of isothermal consolidation of fractured porous media. Comput. Geotech. 1995, 17, 39-73. [CrossRef]

29. Selvadurai, A.P.S. (Ed.) Mechanics of Poroelastic Media; Kluwer Academic Publ.: Dordrecht, The Netherlands, 1996.

30. Selvadurai, A.P.S. Stationary damage modelling of poroelastic contact. Int. J. Solids Struct. 2004, 41, 2043-2064. [CrossRef]

31. Selvadurai, A.P.S. The Analytical Method in Geomechanics. Appl. Mech. Rev. 2007, 60, 87-106. [CrossRef] 
32. Selvadurai, A.P.S. A Multi-Phasic Perspective of the Intact Permeability of the Heterogeneous Argillaceous Cobourg Limestone. Sci. Rep. 2019, 9, 17388. [CrossRef]

33. Selvadurai, A.P.S. The Biot coefficient for a low permeability heterogeneous limestone. Contin. Mech. Thermodyn. 2019, 31, 939-953. [CrossRef]

34. Selvadurai, A. Irreversibility of soil skeletal deformations: The pedagogical limitations of Terzaghi's celebrated model for soil consolidation. Comput. Geotech. 2021, 135, 104137. [CrossRef]

35. Khalili, N.; Selvadurai, A.P.S. A fully coupled Thermo-Hydro-Mechanical for a medium with double porosity. Geophys. Res. Lett. 2003, 30. [CrossRef]

36. Selvadurai, A.P.S.; Shirazi, A. Mandel-Cryer effects in fluid inclusions in damage susceptible poroelastic media. Comp. Geotech 2004, 37, 285-300. [CrossRef]

37. Nguyen, T.; Selvadurai, A.P.S.; Armand, G. Modelling the FEBEX THM experiment using a state surface approach. Int. J. Rock Mech. Min. Sci. 2005, 42, 639-651. [CrossRef]

38. Selvadurai, A.P.S.; Suvorov, A.P. Boundary heating of poroelastic and poro-elastoplastic spheres. Proc. Roy. Soc. Math. Phys. Sci. Ser. A 2012. [CrossRef]

39. Selvadurai, A.P.S.; Suvorov, A.P. Thermo-poromechanics of a fluid-filled cavity in a fluid-saturated geomaterial. Proc. R. Soc. A Math. Phys. Eng. Sci. 2014, 470, 20130634. [CrossRef]

40. Najari, M.; Selvadurai, A.P.S. Thermo-hydro-mechanical response of granite to temperature changes. Environ. Earth Sci. 2014, 72, 189-198. [CrossRef]

41. Nur, A.; Byerlee, J. An exact effective stress law for elastic deformation of rock with fluids. J. Geophys. Res. 1971, 76, 6414-6419. [CrossRef]

42. Selvadurai, A.P.S.; Głowacki, A. Evolution of permeability hysteresis of Indiana Limestone during isotropic compression. Ground Water 2008, 46, 113-119. [CrossRef]

43. Selvadurai, A.P.S.; Selvadurai, P.A.; Nejati, M. A multi-phasic approach for estimating the Biot coefficient for Grimsel granite. Solid Earth 2019, 10, 2001-2014. [CrossRef]

44. Kasani, H.A.; Selvadurai, A.P.S. A review of techniques for measuring Biot's effective stress coefficient for rocks: Recent advances and scientific issues. Geomech. Energy Environ. 2021. under review.

45. Pariseau, W.G. Poroelastic-plastic consolidation-analytical solution. Int. J. Numer. Anal. Methods Geomech. 1999, 23, 577-594. [CrossRef]

46. Suvorov, A.; Selvadurai, A. The Biot coefficient for an elasto-plastic material. Int. J. Eng. Sci. 2019, 145, 103166. [CrossRef]

47. Selvadurai, A.P.S.; Suvorov, A.P. The influence of the pore shape on the bulk modulus and the Biot coefficient of fluid-saturated porous rocks. Sci. Rep. 2020, 10, 18959. [CrossRef] [PubMed]

48. Voigt, W. Lehrbuch der Kristallphysik; Teubner: Leipzig, Germany, 1928.

49. Reuss, A. Berechnung der Fließgrenze von Mischkristallen auf Grund der Plastizitätsbedingung für Einkristalle. J. Appl. Math. Mech. 1929, 9, 49-58.

50. Hill, R. The elastic behaviour of a crystalline aggregate. Proc. Phys. Soc. 1952, 65, 349-354. [CrossRef]

51. Hill, R. Self-consistent mechanics of composite materials. J. Mech. Phys. Solids 1965, 13, 213-222. [CrossRef]

52. Hashin, Z. The elastic moduli of heterogeneous materials. J. Appl. Mech. 1962, 29, 143-150. [CrossRef]

53. Hashin, Z.; Shtrikman, S.A. Variational approach to the theory of elastic behaviour of multiphase materials. J. Mech. Phys. Solids 1963, 11, 127-140. [CrossRef]

54. Beran, M.J. Statistical Continuum Theories; Wiley Interscience: New York, NY, USA, 1968.

55. Brace, W.F. Some new measurements of linear compressibility of rocks. J. Geophys. Res. 1965, 70, 391-398. [CrossRef]

56. Christensen, R.M. Mechanics of Composite Materials; Wiley: New York, NY, USA, 1979.

57. Milton, G.W. The Theory of Composites; Cambridge University Press: Cambridge, UK, 2002.

58. Mavko, G.; Mukerji, T.; Dvorkin, J. The Rock Physics Handbook, Tools for Seismic Analysis of Porous Media; Cambridge University Press: Cambridge, UK, 2009.

59. Markov, K.; Preziosi, L. (Eds.) Heterogeneous Media. Micromechanics Modeling Methods and Simulations; Birkhauser: Boston, MA, USA, 2000.

60. Selvadurai, A.P.S.; Letendre, A.; Hekimi, B. Axial flow hydraulic pulse testing of an argillaceous limestone. Environ. Earth Sci. 2011, 64, 2047-2058. [CrossRef]

61. Walpole, L.J. On bounds for the overall elastic moduli of inhomogeneous systems. J. Mech. Phys. Solids 1966, 14, 151-162. [CrossRef]

62. Hale, D.K. The mechanical properties of composite materials. J. Mat. Sci. 1976, 11, 2105-2141. [CrossRef]

63. Thomsen, L. Elasticity of polycrystals and rocks. J. Geophys. Res. 1972, 77, 315-327. [CrossRef]

64. Kröner, E. Elastic moduli of perfectly disordered composite materials. J. Mech. Phys. Solids 1967, 15, 319-329. [CrossRef]

65. Selvadurai, A.P.S.; Glowacki, A. Stress-induced permeability alterations in an argillaceous limestone. Rock Mech. Rock Eng. 2017, 50, 1079-1096. [CrossRef]

66. TCNA. The Testing Council of North America; Report No TCNA 232-10; Product Testing Services: Anderson, SC, USA, 2010.

67. Martin, C.D.; Chandler, N.A. Progressive failure of Lac du Bonnet granite. Int. J. Rock Mech. Min. Sci. 1994, 31, 643-659. [CrossRef] 
68. Martin, C.D.; Stimpson, B. Effect of sample disturbance on laboratory properties of Lac du Bonnet granite. Can. Geotech. J. 1994, 31, 692-702. [CrossRef]

69. Jackson, R.; Lau, J.S.O.; Annor, A. Mechanical, thermo-mechanical and joint properties of rock samples from the site of the AECL's Underground Research Laboratory, Lac du Bonnet, Manitoba. In Proceedings of the 42nd Canadian Geotechnical Conference, Winnipeg, MB, Canada, 22-25 October 1989; pp. 41-49.

70. Stone, D.; Kamineni, D.C.; Brown, A.; Everitt, R.A. Comparison of fracture styles in two granite bodies of the Superior Province. Can. J. Earth Sci. 1989, 26, 387-403. [CrossRef]

71. Carter, B.J.; Duncan, E.S.; Lajtai, E.Z. Fitting strength criteria to intact rock. Geotech. Geol. Eng. 1991, 9, 73-81. [CrossRef]

72. Read, R.S.; Martin, C.D. Technical Summary of AECL's Mine-by Experiment. Phase 1: Excavation Response; AECL-11311, COG-95-171; Whiteshell Laboratories: Pinawa, MB, Canada, 1996.

73. Tammemagi, H.Y.; Kerford, P.S.; Requeima, J.C.; Temple, C.A.A. Geological Reconnaissance Study of the Lac du Bonnet Batholith; AECL-6439; Whiteshell Nuclear Research Establishment: Pinawa, MB, Canada, 1980.

74. Chernis, P.J.; Robertson, P.B. Thermal Cracking in Lac du Bonnet Granite During Slow Heating to 205 ${ }^{\circ}$ C; AECL-10937, COG-93-358; Whiteshell Nuclear Research Establishment: Pinawa, MB, Canada, 1993.

75. Duevel, B.; Haimson, B. Mechanical characterization of pink lac du Bonnet granite: Evidence of non-linearity and anisotropy. Int. J. Rock Mech. Min. Sci. 1997, 34, 3-4. [CrossRef]

76. Eberhardt, E.; Stimpson, B.; Stead, D. Effect of grain size on the initiation and propagation thresholds of stress-induced brittle fractures. Rock Mech. Rock Eng. 1999, 32, 81-99. [CrossRef]

77. Lukkarila, M.J. Report on Cold Spring Granite; Cemstone Engineering Services: Mendota Heights, MN, USA, 2004.

78. Rietveld, H.M. A profile refinement method for nuclear and magnetic structures. J. Appl. Cryst. 1969, 2, 65-71. [CrossRef]

79. Waber, H.N.; Mäder, U.K.; Koroleva, M.; de Haller, A. Testing Methods for the Characterization of Saline Pore Water in an Ordovician Limestone (Cobourg Formation, St Mary's Quarry, Ontario) Feasibility Study; Technical Report TR 07-01; Rock-Water Interaction (RWI) Institute of Geological Sciences, University of Bern: Bern, Switzerland, 2007.

80. Selvadurai, A.P.S.; Rezaei Niya, S.M. The effective thermal conductivity of an intact heterogeneous limestone. Rock Mech. Geotech. Eng. 2020, 12, 682-692. [CrossRef]

81. Diffrac-Suite. User Manual; Bruker, A.X.S. GmbH: Karlsruhe, Germany, 2011.

82. Alexandrov, K.S.; Rhyzova, T.V.; Beliko, B.P. The elastic properties of pyroxenes. Sov. Phys. Crystallogr. 1964, 8, 589-591.

83. Anderson, O.L.; Nafe, J.E. The bulk modulus -volume relationship for oxide compounds and related geophysical problems. J. Geophys. Res. 1965, 70, 3951-3963. [CrossRef]

84. Carmichael, R.S. Practical Handbook of Physical Properties of Rocks and Minerals; CRC Press: Boca Raton, FL, USA, 1990.

85. Wenning, Q.C.; Madonna, C.; de Haller, A.; Burg, J.-P. Permeability and seismic velocity anisotropy across a ductile-brittle fault zone in crystalline rock. Solid Earth 2018, 9, 683-698. [CrossRef]

86. Ramakrishnan, N.; Arunachalam, V.S. Effective elastic moduli of porous ceramic materials. J. Am. Ceramic. Soc. 1993, 76, 2745-2752. [CrossRef]

87. Lau, J.S.O.; Chandler, N.A. Innovative laboratory testing. Int. J. Rock Mech. Min. Sci. 2004, 41, 1427-1445. [CrossRef]

88. Rutqvist, J.; Borgesson, L.; Chijimatsu, M.; Hernelind, J.; Jing, L.; Kobayashi, A.; Nguyen, T.S. Modeling of Damage, Permeability Changes and Pressure Responses during Excavation of TSX Tunnel in Granite Rock at URL, Canada. 2009. Available online: https:/ / escholarship.org/uc/item/8f12b5cf (accessed on 1 June 2020).

89. Chan, T.; Stanchell, F.W. DECOVALEX THMC TASK E-Implications of Glaciation and Coupled Thermohydromechanical Processes on Shield Flow System Evolution and Performance Assessment; NWMO TR-2008003; Nuclear Waste Management Organization: Toronto, ON, Canada, 2008.

90. Cosenza, P.; Ghoryechi, M.; de Marsily, G.; Vasseur, G.; Violette, S. Theoretical prediction of poroelastic properties of argillaceous rocks from in situ specific storage coefficient. Water Res. Res. 2002, 38. [CrossRef]

91. Rice, J.R.; Cleary, M.P. Some basic stress diffusion solutions for fluid-saturated elastic porous media with compressible constituents. Rev. Geophys. Space Phys. 1976, 14, 227-241. [CrossRef]

92. Cheng, A.-H.D.; Detournay, E. Fundamentals of poroelasticity, Chapter 5 in Comprehensive Rock Engineering: Principles, Practice and Projects. In Analysis and Design Method; Fairhurst, C., Ed.; Pergamon Press: Oxford, UK, 1993; Volume II, pp. 113-171.

93. Bouteca, M.; Sarda, J.-P. Elements of thermo-poroelasticity. In Mechanics of Porous Media; Charlez, P.A., Ed.; Balkema: Rotterdam, The Netherlands, 1995; pp. 21-30.

94. Charlez, P. Rocks Mechanics. In Petroleum Applications; Technip: Paris, France, 1997; Volume II.

95. Fabre, D.; Gustkiewicz, J. Poroelastic properties of limestones and sandstones under hydrostatic conditions. Int. J. Rock Mech. Min. Sci. 1997, 34, 127-134. [CrossRef]

96. Berryman, J.G. Effective stress for transport properties of inhomogeneous porous rock. J. Geophys. Res. 1992, 97, 17409-17424. [CrossRef]

97. Wang, H.F. Quasi-static poroelastic parameters in rock and their geophysical applications. Pure Appl. Geophys. 1993, 141, 269-286. [CrossRef]

98. Souley, M.; Lopez, P.; Boulon, M.J.; Thoraval, A. Experimental hydromechanical characterization and numerical modelling of a fractured and porous sandstone. Rock Mech. Rock Eng. 2015, 48, 1143-1161. [CrossRef] 
99. Hu, C.; Agostini, F.; Skoczylas, F.; Jeannin, L.; Potier, L. Poromechanical properties of a sandstone under different stress states. Rock Mech. Rock Eng. 2018, 51, 3699-3717. [CrossRef]

100. Chen, Y.; Selvadurai, A.P.S.; Liang, W. Computational modelling of groundwater inflow during a longwall coal mining advance: A Case study from the Shanxi Province China. Rock Mech. Rock Eng. 2019, 52, 917-934. [CrossRef]

101. Selvadurai, A.P.S.; Zhang, D.; Kang, Y. Permeability evolution in natural fractures and their potential influence on loss of productivity in ultra-deep gas reservoirs of the Tarim Basin, China. J. Nat. Gas Sci. Eng. 2018, 58, 162-177. [CrossRef]

102. Braun, P.; Ghabezloo, S.; Delage, P.; Sulem, J.; Conil, N. Determination of multiple thermo-hydro-mechanical rock properties in a single transient experiment: Application to shales. Rock Mech. Rock Eng. 2019, 52, 2030-2038. [CrossRef]

103. Chen, R.; Xia, K. Determination of Dynamic Fracture Properties of Rocks Using Semi-Circular Bend Technique; Sanchidrian, J., Ed.; Taylor and Francis Group: London, UK, 2010; pp. 51-57.

104. Wang, H.F. Theory of Linear Poroelasticity with Applications to Geomechanics and Hydrogeology; Princeton University Press: Princeton, NJ, USA, 2000.

105. Zimmerman, R.W.; Somerton, W.H.; King, M.S. Compressibility of porous rocks. J. Geophys. Res. 1986, 91, 12765-12777. [CrossRef]

106. Zimmerman, R.W. Coupling in poroelasticity and thermoelasticity. Int. J. Rock Mech. Min. Sci. 2000, 17, 79-87. [CrossRef]

107. Schmitt, D.R.; Zoback, M.D. Poroelastic effects in the determination of the maximum horizontal principal stress in hydraulic fracturing tests-A proposed breakdown equation employing a modified effective stress relation for tensile fracture. Int. J. Rock Mech. Min. Sci. 1989, 26, 499-506. [CrossRef]

108. Duan, Z.; Skoczylas, F. Experimental study of the permeability and poromechanical properties of thermally damaged granite. Eur. J. Environ. Civ. Eng. 2019, 25. [CrossRef]

109. Tan, X.; Konietzky, H. Numerical study of Biot's coefficient evolution during failure process for Aue granite using an empirical equation based on GMR Method. Rock Mech. Rock Eng. 2017, 50, 1683-1689. [CrossRef]

110. Coyner, K.B. Effects of Stress, Pore Pressure, and Pore Fluids on Bulk Strain, Velocity, and Permeability of Rocks. Ph.D. Thesis, Massachusetts Institute of Technology, Cambridge, MA, USA, 1984.

111. Selvadurai, A.P.S.; Selvadurai, P.A. Surface permeability tests: Experiments and modelling for estimating effective permeability. Proc. Roy. Soc. Math. Phys. Sci. Ser. A 2010, 466, 2819-2846. [CrossRef] 